\title{
Helicobacter pylori除菌による胃癌予防：最近の知見
}

\section{加藤 元嗣 浅香 正博}

要旨

Helicobacter pylori (H. pylori) は生涯に渡って胃粘膜に感染して胃炎を惹起する. 慢性胃炎を背景とし て胃・十二指腸潰瘍, 胃癌などの様々な上部消化管疾患が起きる. 胃癌は組織型を問わずH. pylori感染 粘膜から発生することがほとんどである，高度の萎縮，腸上皮化生，体部胃炎では分化型胃癌が，非萎 縮や全体胃炎では未分化型癌の発生が高く, 背景粘膜の炎症や萎縮の程度によって, 胃癌リスクが異な る. 動物実験ではH. pylori除菌が胃癌発生を抑制することが認められ，除菌を早期に行う方が胃癌予防 の効果は強い. 中国でのH. pylori除菌による無作為二重盲検比較試験では, 除菌は胃癌発症を抑制しな いとの結果であった. しかし, 胃癌の内視鏡的切除後の異時性多発癌をエンドポイントとした無作為化 試験がわが国で行われ, H. pylori除菌によって有意に異時癌の発症が抑制された. H. pylori除菌は胃癌の 発育進展を抑制すると推測できる。胃癌撲滅のために，H. pylori除菌を基本に据えた施策を早急に計画 するべき時期に入ったといえる.

〔日内会誌 $98 ： 2614 \sim 2620,2009$ ]

Key words : H. pylori, 除菌治療, 胃発癌, 二次胃癌

\section{はじめに}

Helicobacter pylori (H. pylori) はヒトの胃粘膜 に感染して胃炎を引き起こす．多くの場合， H. pyloriは生涯に渡って感染し続けるので, 胃粘膜 の炎症は持続する，慢性胃炎を背景として，萎 縮性胃炎, 胃・十二指腸潰瘍, 胃癌, 胃MALT (mucosa-associated lymphoid tissue) リンパ腫, 胃過形成性ポリープなどの様々な上部消化管疾 患が起こる.さらには, H. pylori感染は胃酸分泌 能など胃機能の面にも影響を与え, 胃内環境の 変化をもたらしている.

胃癌は組織型を問わずH. pylori感染粘膜から発 生することがほとんどで, 炎症のない胃粘膜か ら胃癌が発生することはまれである. H. pylori

かとうもとつぐ：北海道大学病院光学医療診療部

あさか まさひろ：北海道大学消化器内科
感染は胃発癌と最も強く関連する因子である. わが国ではH. pylori感染者の多くが萎縮性胃炎に 移行するが, 粘膜萎縮や腸上皮化生の存在は胃 癌リスクを高める。世界保健機構（WHO）の下 部組織である国際癌研究機関 (IARC) は 1994 年に疫学的成績から, H. pyloriを胃癌におけるdefinite carcinogen (明確な発癌因子)に指定した1). その後H. pyloriの感染モデルであるスナネズミを 用いた動物実験，わが国におけるヒトでの前向 き研究などから, H. pylori感染と胃癌の関連につ いては明らかにされた. そこで, H. pylori除菌が 胃癌の発生や発育進展になんらかの影響を及ぼ す可能性が指摘され, 臨床において介入試験が 行われてきた。 わが国で行われた大規模な無作 為比較試験で, H. pylori除菌による胃発癌の抑制 効果が明らかになった2). 


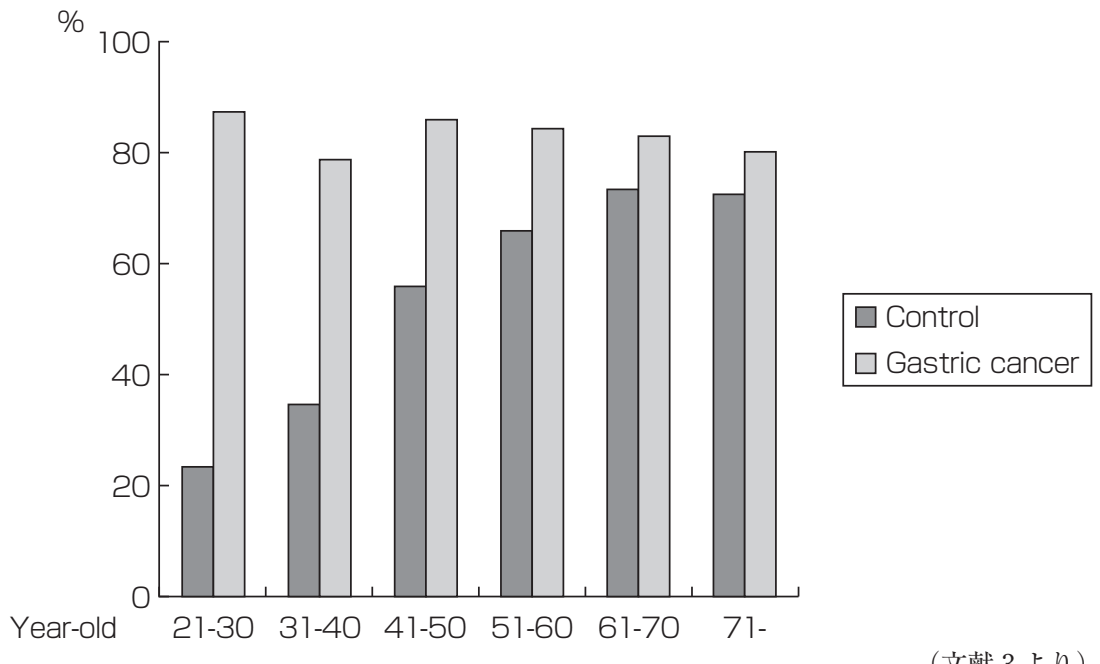

図 1. 胃癌患者と健常人におけるH. pylori 抗体陽性率

\section{H. pylori感染と胃癌の関連性}

H. pylori感染と胃癌の関連については, 疫学研 究, 感染モデル実験, 臨床試験から検討されて きた.これまで多くの疫学研究がなされてきた が, 中でも信頼性の高いnested case-control studyのメ夕解析では, 胃癌におけるH. pylori 感染のオッズ比は 2.5(95\% 信頼区間 1.9〜 3.4) と 報告された。多数のcross-sectional case-control studyのメ夕解析では, 噴門部以外の癌において 分化型癌, 未分化型癌ともにH. pylori感染との関 連が強いことが示された。わが国での胃癌患者 のH. pylori罹患率はH. pylori抗体による検討では 各年代を通じて約 $90 \%$ と一定であるが, 健常人 のH. pylori罹患率は若年から中高年にかけて上昇 する，そのため，高歯者では健常人の罹患率が 高いため, 若年者における胃癌ほどH. pylori感染 のオッズ比は高くなる(図 1) ${ }^{3)}$. 動物実験に関し ては,わが国から多くの成績が報告されている. スナネズミはH. pylori感染によってヒトと類似し た胃粘膜の炎症を惹起するため, 胃潰瘍の感染 モデルとして用いられていた.しかし, H. pylori の長期感染によってスナネズミに胃癌の発症が
確認された4).さらには, スナネズミにおいて $H$. pylori感染は発癌物質である $\mathrm{N}-$ ニロソ化合物に よる胃癌の発症率を有意に増加させる作用が明 らかとなった. また, H. pylori感染は, 従来胃癌 のリスクファクターとされていた高濃度の塩分 よりも強い胃癌促進作用を示した.

前向きの臨床研究として, Uemuraらは平均 8 年間の内視鏡による経過観察を行い, H. pylori 感染者（1,246 例）からは $2.9 \%$ に胃癌が発生し たが, 非感染群 (280 例) からは胃癌の発生は認 めなかった5) (図 2). また, H. pylori陽性者の中で も, 胃癌発生は十二指腸潰瘍患者では認めず, 胃潰瘍，胃ポリープ，萎縮性胃炎の患者から認 められた。さらに, 高度の萎縮例, 腸上皮化生 例，体部胃炎例では分化型胃癌の発症が多く, 非萎縮例や全体胃炎では未分化型胃癌の発生が 多いことも判明した。これらの結果は, H. pylori 感染に伴う背景胃粘膜の炎症や萎縮の程度によっ て, 胃癌発症のリスクや発生する胃癌の組織型 が異なることを示している.H. pylori感染に伴う 慢性胃炎は，炎症の首座によって，前庭部優位 胃炎, 全体胃炎, 体部優位胃炎に大別される(図 3)。これらの胃炎タイプと発症する疾患には強 い関連があり,十二指腸潰瘍は前庭部優位胃炎, 


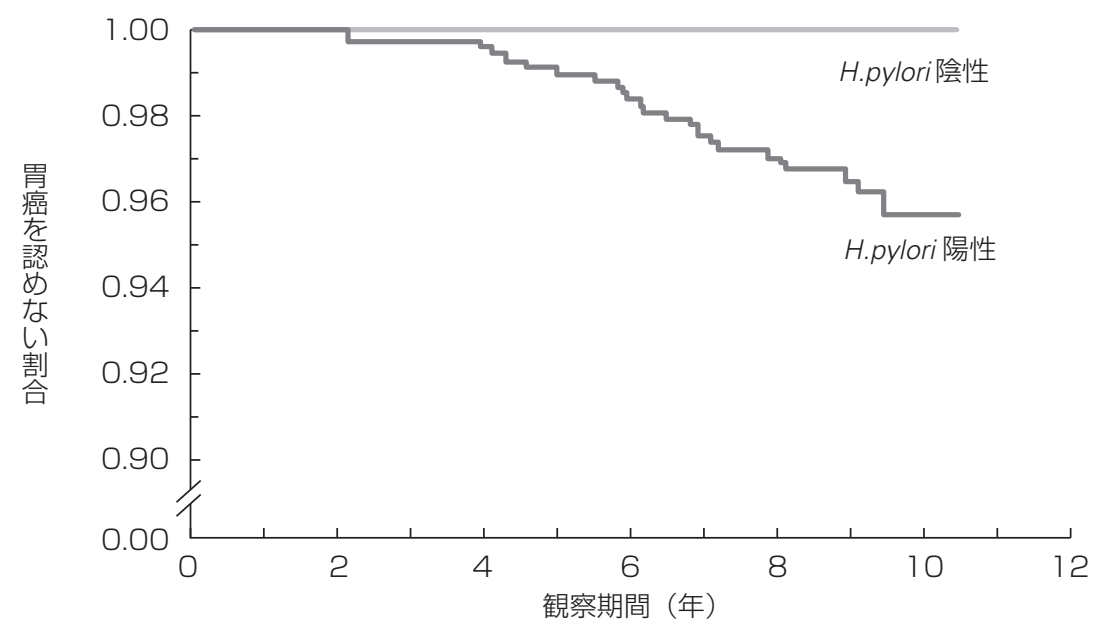

(文献 5 より)

図 2. H. pylori 陽性群と陰性群における胃癌の発生

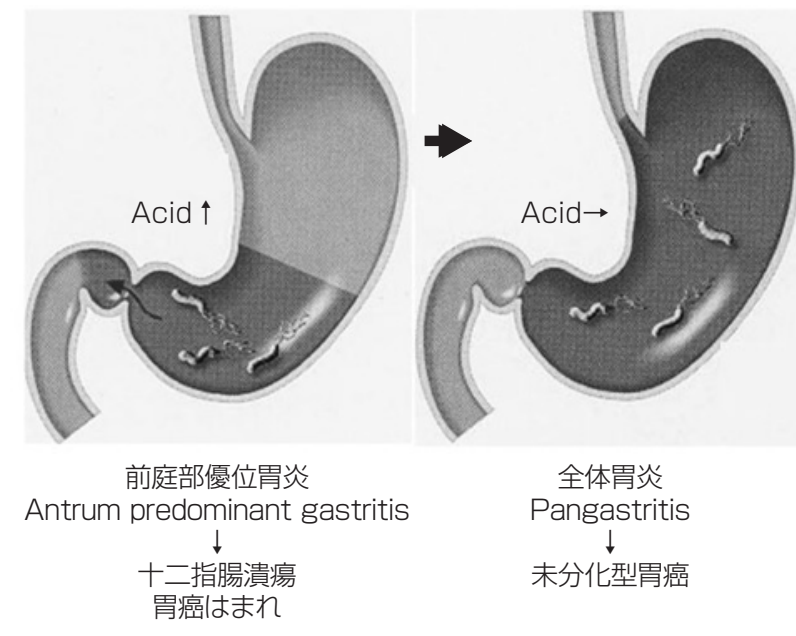

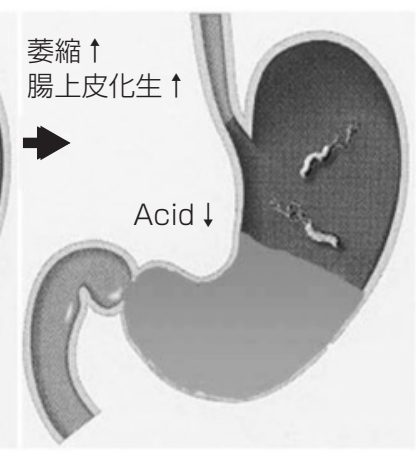

体部優位胃炎

Corpus predominant gastritis

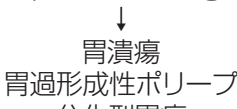

分化型胃癌

図 3. H. pylori感染胃炎のタイプ

胃潰瘍や胃過形成性ポリープは体部優位胃炎を 背景粘膜として発症する。すなわち, 酸分泌能 が充進する前庭部優位胃炎からは胃癌の発症は 少ないが，萎縮や腸上皮化生が出現して酸分泌 能の低下する体部優位胃炎では分化型胃癌が発 症しやすい。 また, 全体胃炎からは未分化型胃 癌が発症することが多い。この胃炎夕イプの割 合には民族差があり，日本を含む東アジアでは 胃体部優位胃炎の頻度が高く胃癌のリスクが高
い.しかし，アングロサクソン系では前庭部優 位胃炎の頻度が高く,H. pylori感染者からの胃癌 発症は少ない。

\section{2. 胃癌に対する介入試験}

H. pylori感染と胃癌の因果関係を明確にするに は介入試験による成績が重要である. 動物実験 ではH. pylori感染スナネズミにN-ニトロソ化合物 
表 1. 胃癌に対する無作為化介入試験

\begin{tabular}{|c|c|c|c|c|c|c|c|}
\hline \multirow{2}{*}{ Author } & \multirow{2}{*}{$\begin{array}{c}\text { Double } \\
\text { blind }\end{array}$} & \multirow{2}{*}{$\begin{array}{c}\text { Placebo } \\
\text { control }\end{array}$} & \multirow{2}{*}{$\begin{array}{c}\text { Follow } \\
\text { (year) }\end{array}$} & \multicolumn{3}{|c|}{ Incidence of gastric cancer } & \multirow{2}{*}{$\begin{array}{l}\text { Outcome } \\
\text { measure }\end{array}$} \\
\hline & & & & Eradication & Control & P-value & \\
\hline Wong & Yes & Yes & 7.5 & $7 / 817$ & $11 / 813$ & 0.33 & primary \\
\hline Leung & Yes & Yes & 5 & 4/220 & $6 / 215$ & 0.65 & secondary \\
\hline Mera & No & No & 12 & 5/394 & $4 / 401$ & 1.28 & secondary \\
\hline Zhou & Yes & Yes & 8 & $1 / 276$ & $6 / 276$ & 0.16 & secondary \\
\hline You & Yes & Yes & 7.3 & $19 / 1130$ & $27 / 1128$ & 0.70 & secondary \\
\hline
\end{tabular}

Fuccio 2007 ; APT $25: 133-141$

の発癌物質を併用すると胃癌発生率が高くなる が, $\mathrm{N}$ 一ニトロソ化合物投与後にH. pylori除菌を行 うと, 胃癌の発生率が $\mathrm{N}$-ニトロソ化合物単独投 与のレベルまで下がることが報告された ${ }^{6)}$.さら に, 除菌する時期を早期 (15W), 中期 (35W), 晚期（55W）に分けて比較すると，発癌率は除 菌のない対照群で $56.3 \%$, 晚期群は $38.2 \%$, 中期 群は $27.3 \%$, 早期群は $6.7 \%$ と, H. pylori除菌を 早期に行う方が胃癌予防の効果は強かった ${ }^{7)}$.こ れらの動物実験の成績はH. pylori除菌による胃癌 の一次予防としての可能性を示した。

Wongらは胃癌予防を第一エンドポイントとし たプラセボ対照による無作為二重盲検比較試験 による大規模な介入試験の成績を示した ${ }^{8)}$. 胃癌 死亡率の高い中国福建省の一般住民のH. pylori 感染者 1,630 名を対象とした. H. pylori除菌治療 群 $(\mathrm{n}=817)$ もしくはプラセボ投与群 $(\mathrm{n}=813)$ に無作為に分け，1994 年から 2002 年まで 7.5 年間追跡した。初回登録時と 5 年後に全例に, さらに必要時に内視鏡検査を実施した。除菌に は 3 剂併用 2 週間を用い, 失敗時は再除菌を行っ た (最終除菌率は $83.7 \%$ )。追跡期間中に除菌群 から 7 名, プラゼボ群から 11 名の胃癌の発症が 認められ, 両群間に有意な差はなかった $(\mathrm{P}=0.33)$.

しかし, 前癌性病変 (委縮, 腸上皮化生, 異形 成）のないサブグループにおいて，除菌群の胃 癌発症はなく, プラセボ群 $(\mathrm{n}=6)$ に比べて有 意に低率であった $(\mathrm{P}=0.02)$ ，この成績から $H$. pylori除菌に胃癌予防効果がないと結論づけるこ
とは困難である。考察では胃癌のリスクを評価 するには観察期間が短かった可能性が述べられ ている.

エンドポイントを胃炎の進展に設定した無作 為化介入試験で, 胃発癌を第二のエンドポイン トとした成績が報告されている. しかし，H.pylori除菌の胃癌予防に関しては個々の試験および メ夕解析においても有意な結果が得られなかっ た ${ }^{9)}$ (表 1). 初発胃癌を対象とする臨床研究の場 合には, 胃癌の発生率が低いために多数例の登 録と長期間の観察が必要となる。そのため，観 察期間, 癌の検出能, 対象の年齢, 環境因子な どによって結果が影響を受けやすいと考える.

\section{3. わが国での胃癌に対する介入試験}

除菌後胃癌の出現を検討した臨床試験がわが 国から報告されている ${ }^{10}$ (表 2). Takeらは消化性 潰瘍患者にH. pylori除菌後 1 年以上にわたり経過 観察を前向きに検討した。平均観察期間が 3.4 年で, 除菌成功群 $(\mathrm{n}=944)$ から 8 例, 除菌に 失敗したH. pylori感染持続群 $(\mathrm{n}=176)$ から 4 例の胃癌が発見された。胃癌の発見率は除菌群 で $0.8 \%$, 感染群 $2.3 \%$ で, 5 年間での胃癌発生率 は $1.21 \%$, 感染群では $3.80 \%$ と有意差を認めた. Takenakaらは平均約 3 年間の経過観察により除 菌群 1,519 例から 6 例 $(0.4 \%)$, 感染群 288 例か ら 5 例 $(1.7 \%)$ の胃癌が発見され, 有意に除菌 群での胃癌発現率は低いと報告した.また, Ogura 
表 2. 胃癌の非無作為化介入試験

\begin{tabular}{|c|c|c|c|c|c|c|c|}
\hline 報告者 & 年 & 症例 & 群 & 観察（年） & 胃癌発生率（\%） & 分化型 & 未分化型 \\
\hline $\begin{array}{l}\text { Take } \\
\text { prospective } \\
\text { Takenaka } \\
\text { prospective } \\
\text { Ogura } \\
\text { prospective }\end{array}$ & $\begin{array}{l}2005 \\
2007 \\
2008\end{array}$ & $\begin{array}{r}1,342 \\
1,807 \\
708\end{array}$ & $\begin{array}{l}\text { 感染 } \\
\text { 除菌 } \\
\text { 感染 } \\
\text { 除菌 } \\
\text { 感染 } \\
\text { 除菌 }\end{array}$ & $\begin{array}{l}3.4 \\
3.4 \\
2.9 \\
3.3 \\
3.1 \\
3.2\end{array}$ & 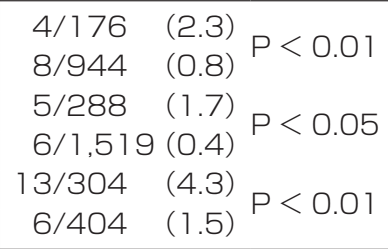 & $\begin{array}{l}0 \\
5 \\
1 \\
2 \\
2 \\
3\end{array}$ & $\begin{array}{r}4 \\
3 \\
4 \\
4 \\
11 \\
3\end{array}$ \\
\hline $\begin{array}{l}\text { Kato } \\
\text { retrospective }\end{array}$ & 2006 & 3,021 & $\begin{array}{l}\text { 感染 } \\
\text { 除菌 }\end{array}$ & $\begin{array}{l}7.7 \\
5.9\end{array}$ & $\begin{array}{l}44 / 1,233(3.6) \\
23 / 1,788(1.3)\end{array} P<0.01$ & $\begin{array}{l}32 \\
19\end{array}$ & $\begin{array}{r}12 \\
4\end{array}$ \\
\hline
\end{tabular}

らは 708 例を平均約 3.2 年の経過観察を行い, 胃 癌発現率は除菌群で $1.5 \%(6 / 40)$, 感染群では 4.3\%（13/304）で有意に除菌群での胃癌発見率 は低かった。これまでの非無作為化試験の結果 ではいずれの報告でもH. pylori除菌によって胃癌 発現が約 3 分の 1 に抑制され，除菌による胃癌 の予防効果が示された.我々はH. pylori除菌治療 後の胃発癌について後ろ向き研究を報告した. 年 1 回の内視鏡検査で 5 年以上の経過観察中, 胃癌の年間発現率は非除菌群で $0.45 \%$, 除菌群で $0.22 \%$ と有意差を認めた。

胃癌の内視鏡的切除後の経過観察中に, 切除 した部位とは別の部位に異時性多発癌 (二次癌) を認めることがある。これまでの報告では経過 観察期間が一定していないが，二次癌の割合は 2.5 14\% と報告されている.内視鏡治療では胃 臓器が温存されるために, H. pylori感染によって 胃全体がfield carcinogenesisの状態になってお り, 内視鏡的切除後に二次癌が出現してくる. Uemuraらは内視鏡的治療を行った早期胃癌症例 を,H. pylori除菌群と非除菌群に分け長期の経過 観察を行った。論文化された時点では平均 5 年 の経過観察がされ, 非除菌群 67 例のうち 10 例 (15\%) に二次胃癌の出現を認め, 除菌群 65 例 では二次癌の発現を認めなかった ${ }^{11)}$.その後さら に経過観察を続けていると除菌群で 4 年目に二 次癌の発現を 1 例認めた。短期間の経過観察中 にH. pylori除菌が新たな胃癌の発生を抑制したと は考え難く, 治療時に存在する二次癌の発育進
展をH. pylori除菌が抑制するために, 内視鏡で検 出される時期が遅れると考察される.この研究 は大変先駆的であったが，無作為化が厳密でな い点でRCT（randomized controlled trial）との 評価が得られなかった.

Japan Gast Study Group（JGSG）(代表浅香正 博) では, 胃発癌を一次のエンドポイントとし た無作為化試験としてUemura研究の追試が多施 設で行われた ${ }^{2)}$. 早期胃癌の内視鏡治療が予定さ れている（新規EMR群）または治療後に経過観 察されている（経過観察群）の 544 例が登録さ れ，除菌群と対照群に振り分けられた。登録後 は 6 力月目, 1 年目, 2 年目, 3 年目に内視鏡検 查を行い, 二次癌と胃残再発の出現を検討した. 最終的に除菌群 255 例，対照群 250 例が解析さ れた。除菌群と対照群の患者背景や一次胃癌の 形態に差がなかった。両群とも腸上皮化生を前 庭部で約 $65 \%$, 体部で約 $45 \%$ に認め, 萎縮の程 度は中等度以上が約 $80 \%$, 萎縮範囲はC3 以上が 約 $90 \%$ であった. 3 年間の観察期間中に 33 例の 二次癌を認め, 除菌群で 9 例, 対照群で 24 例と 有意差を認めた（ハザード比：0.339, $95 \%$ IC： $0.157 \sim 0,729, \mathrm{p}=0.003)$. 両群間に年齢, 性別, 出現部位, 組織型, 深達度, 大きさには差を認 めなかった，累積発症率で見ても両群間には差 が認められ，両群のリスク比は 3 年以降も続い た（図 4). 一方，不完全切除による遺残再発は 18 例で, 除菌群で 8 例, 対照群で 10 例と有意差 を認めなかった. 従って, H. pylori除菌が二次癌 


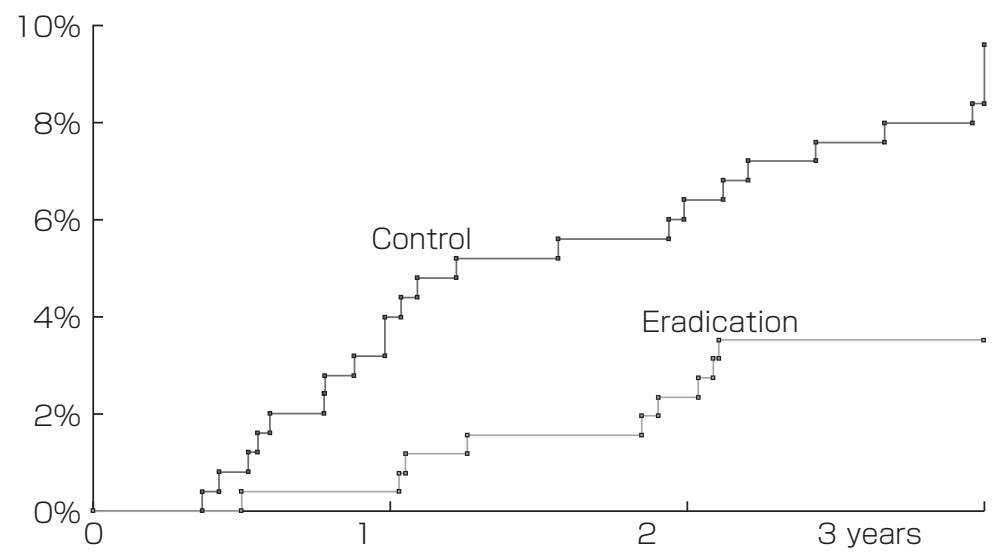

Numbers of subjects at risk
Control 255
237
196
157
Eradication 250
250
213
167

(文献2より)

図 4. 二次胃癌の出現率
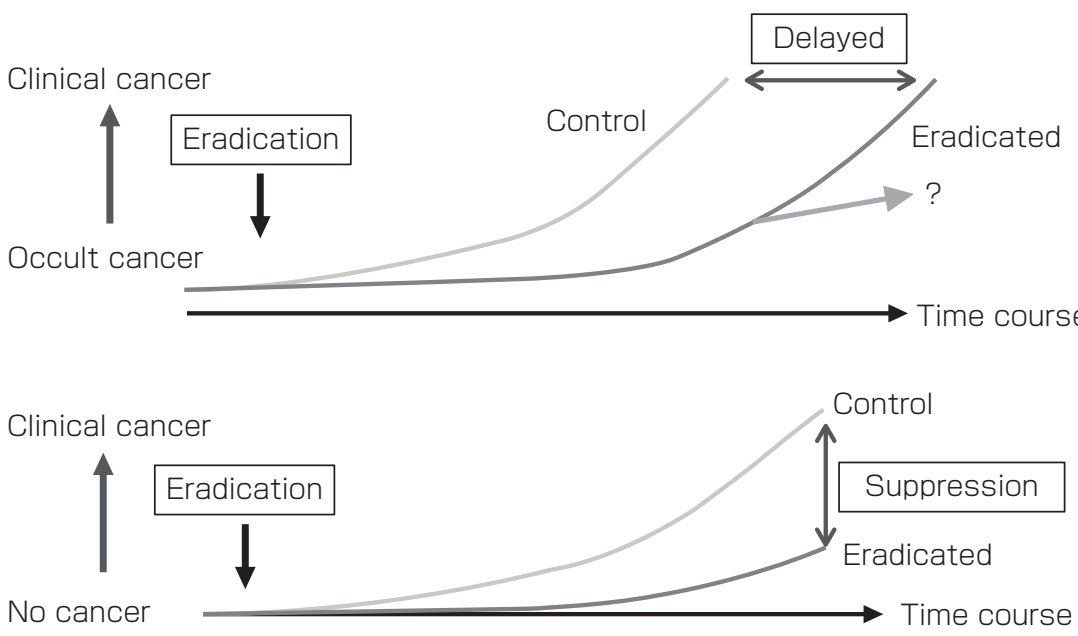

図 5. 胃癌の発育進展におけるH. pylori 除菌効果

の出現を明らかに抑制したと結論した.これは, H. pylori除菌による介入を行い, 胃癌の発生を一 次のエンドポイントとした無作為化試験で初め て有意差が得られた試験である。

\section{おわりに}

これまでの成績からH. pylori除菌の胃癌に対す る役割は, 胃癌の発育進展を遅らせ, また発癌
への抑制作用があると推測できる (図 5) ${ }^{12}$. JGSG 研究から粘膜萎縮および腸上皮化生の存在する 早期胃癌患者でも, H. pylori除菌は胃癌の予防効 果を有することから,一般のH. pylori感染者につ いても, 除菌は胃癌予防に有効があると考えら れる. 胃癌撲滅を目標に, 日本政府はH. pylori 除菌による胃癌予防の処置を直ちに考慮すべき である. 当初は費用がかかっても, 予防効果の 発揮によって 5 年で 5 千億円以上の経済効果を 
もたらし， 5 年間で 14 万人もの命を救える可能 性がある.これにより 50〜60 年かかると思われ た欧米並みへの胃癌発生の減少は 10～20 年で達 成できる可能性がある。 わが国における胃癌撲 滅のために, H. pylori除菌を基本に据えた施策を 行政が早急に実行すべき時期に入ったといえる.

\section{文献}

1) International Agency for Research on Cancer, World Health Organization : Schistosomes, liver flukes and Helicobacter pylori. IARC Monogr Eval Carcinog Risk Hum 61: 177-241, 1994.

2) Fukase K, et al: Effect of eradication of Helicobacter pylori on incidence of metachronous gastric carcinoma after endoscopic resection of early gastric cancer : an openlabel, randomised controlled trial Lancet 372(9636) : 392397, 2008.

3) Kato M, et al: Relationship between Helicobacter pylori infection and the prevalence, site and histological type of gastric cancer. Aliment Pharmacol Ther 20 (Suppl 1): 85-89, 2004.

4) Watanabe $\mathrm{T}$, et al:Helicobacter pylori infection induces gastric cancer in mongolian gerbils. Gastroenterology 115 : 642-648, 1998.

5) Uemura N, et al : Helicobacter pylori infection and the de- velopment of gastric cancer. N Engl J Med 345 : 784-789, 2001.

6) Shimizu N, et al : Eradication diminishes enhancing effects of Helicobacter pylori infection on glandular stomach carcinogenesis in Mongolian gerbils. Cancer Res 60: 1512-1514, 2000.

7) Nozaki K, et al: Effect of early eradication on Helicobacter pylori-related gastric carcinogenesis in Mongolian gerbils. Cancer Sci 94 : 235-239, 2003.

8) Wong BC, et al: Helicobacter pylori eradication to prevent gastric cancer in a high-risk region of China : a randomized controlled trial. JAMA 291 : 187-194, 2004.

9) Fuccio L, et al: Systematic review: Helicobacter pylori eradication for the prevention of gastric cancer. Aliment Pharmacol Ther 25 : 133-134, 2007.

10) 加藤元嗣, 他 : 胃癌化学予防H. pylori除菌療法を中心に. 臨床消化器内科 23 (12) : 1651-1658, 2008.

11) Uemura $\mathrm{N}$, et al : Effect of Helicobacter pylori eradication on subsequent development of cancer after endoscopic resection of early gastric cancer. Cancer Epidemiol Biomarkers Prev 6 : 639-642, 1997.

12) Kato M, et al: Eradication of Helicobacter pylori for primary gastric cancer and secondary gastric cancer after EMR. J Gastroenterol 42 (Suppl 17) : 16-20, 2007.

13) Talley NJ : Time to screen and treat $H$. pylori to prevent gastric cancer? Lancet 372 (9636) : 350-352, 2008. 